\title{
SH2B Adapter Protein 3
}

National Cancer Institute

\section{Source}

National Cancer Institute. SH2B Adapter Protein 3. NCI Thesaurus. Code C102804.

SH2B adapter protein 3 ( $575 \mathrm{aa}, \sim 63 \mathrm{kDa}$ ) is encoded by the human SH2B3 gene. This protein plays a role in $\mathrm{T}$-cell receptor signaling. 